\title{
Adaptation and Virulence of Enterovirus-A71
}

\author{
Kyousuke Kobayashi and Satoshi Koike*
}

Neurovirology Project, Tokyo Metropolitan Institute of Medical Science, Tokyo 156-8506, Japan; kobayashi-ks@igakuken.or.jp

* Correspondence: koike-st@igakuken.or.jp; Tel.: +81-3-5316-3347

\section{check for}

updates

Citation: Kobayashi, K.; Koike, S. Adaptation and Virulence of Enterovirus-A71. Viruses 2021, 13, 1661. https://doi.org/10.3390/ v13081661

Academic Editor: Hironori Sato

Received: 21 July 2021

Accepted: 19 August 2021

Published: 21 August 2021

Publisher's Note: MDPI stays neutral with regard to jurisdictional claims in published maps and institutional affiliations.

Copyright: (c) 2021 by the authors. Licensee MDPI, Basel, Switzerland. This article is an open access article distributed under the terms and conditions of the Creative Commons Attribution (CC BY) license (https:// creativecommons.org/licenses/by/ $4.0 /)$.

\begin{abstract}
Outbreaks of hand, foot, and mouth disease caused by enterovirus-A71 (EV-A71) can result in many deaths, due to central nervous system complications. Outbreaks with many fatalities have occurred sporadically in the Asia-Pacific region and have become a serious public health concern. It is hypothesized that virulent mutations in the EV-A71 genome cause these occasional outbreaks. Analysis of EV-A71 neurovirulence determinants is important, but there are no virulence determinants that are widely accepted among researchers. This is because most studies have been done in artificially infected mouse models and because EV-A71 mutates very quickly to adapt to the artificial host environment. Although EV-A71 uses multiple receptors for infection, it is clear that adaptation-related mutations alter the binding specificity of the receptors and allow the virus to adopt the best entry route for each environment. Such mutations have confused interpretations of virulence in animal models. This article will discuss how environment-adapted mutations in EV-A71 occur, how they affect virulence, and how such mutations can be avoided. We also discuss future perspectives for EV-A71 virulence research.
\end{abstract}

Keywords: enterovirus-A71; virulence determinant; adaptation; mutation; infection animal model

\section{Epidemiology of Enterovirus-A71 (EV-A71)}

Enterovirus A (EV-A) belonging to the genus Enterovirus (family, Picornaviridae) has various serotypes. Serotypes, such as Coxsackievirus A6 (CVA6), CVA10, CVA16, and EVA71, cause hand, foot, and mouth disease (HFMD). Usually, HFMD is an infectious disease that mainly affects infants and young children, with the primary symptom being a bullous rash on the oral mucosa, hands, and feet. Unlike other serotypes, EV-A71 can sometimes cause central nervous system (CNS) complications, such as meningitis, cerebellar ataxia, acute flaccid paralysis, encephalitis, and pulmonary edema. Outbreaks of HFMD, in which many patients develop CNS complications caused by EV-A71, have occurred sporadically in the Asia-Pacific region, including Malaysia, Taiwan, Mainland China, Vietnam, and Cambodia since the late 1990s [1-11]. It is an infectious disease with serious public health implications because a large-scale outbreak can result in many deaths.

\section{Viral Replication}

EV-A71 has a single-stranded plus-stranded RNA genome [12] of about 7400 bases encapsulated by a non-enveloped capsid. The genome encodes a single polyprotein of about 2200 amino acid residues, cleaved into three precursor proteins (P1, P2, and P3) after translation. These are cleaved further to yield 11 different viral proteins. Four capsid proteins arise from P1, and seven nonstructural viral proteins arise from P2 and P3. The polyprotein coding region is flanked by $5^{\prime}$ - and $3^{\prime}$-untranslated regions (UTRs). Functional RNA structures on the UTRs, such as internal ribosome entry sites (IRES) and cloverleaf, cooperate with viral proteins and host proteins to translate viral proteins and replicate the RNA genome. Therefore, amino acid mutations in viral proteins may alter their activity, or nucleotide mutations in the UTRs may alter translation and replication efficiency, thereby altering virulence. 
Virus receptors on the cell surface mediate the early infection steps: Virion attachment to the host cell surface; internalization into the cell; and uncoating and releasing genomic RNA from the capsid into the cytoplasm. Scavenger receptor class B member 2 (SCARB2), a well-studied receptor for EV-A71, can mediate these steps [13,14]. Co-crystallographic analysis with EV-A71 particles and SCARB2 revealed that several amino acids in the VP2 EF-loop and VP1 GH-loop on the virion are involved in the binding to SCARB2 [15]. However, since SCARB2 is naturally a lysosomal protein, its expression at the cell surface is low. Therefore, under certain conditions, receptors other than SCARB2, called attachment receptors, may assist the virus, and enable efficient infection. Attachment receptors include P-selectin glycoprotein ligand 1 (PSGL1) [16], heparan sulfate (HS) [17], sialic acid [18], annexin II [19], nucleolin [20], vimentin [21], and fibronectin [22]. Among these, HS and PSGL1 are well described. HS is a highly sulfated glycosaminoglycan biosynthesized in cells as a proteoglycan bound to a protein backbone. HS proteoglycans, which play a physiological role by binding to various ligand molecules, are expressed on the surface or secreted extracellularly [23]. PSGL1 is a type I transmembrane protein expressed on the surface of neutrophils, monocytes, and most lymphocytes. Tyrosine sulfation near the $\mathrm{NH}_{2}$-terminus of PSGL1 is necessary for EV-A71-binding [24]. EV-A71 particles bind to human PSGL1, but not mouse PSGL1 [16]. Among these attachment receptors, HS plays an important role in the adaptation of EV-A71 in cell culture.

After the viral genome is released into the cytoplasm, translation of viral proteins occurs in an IRES-dependent manner, and replication of the viral genome occurs via RNAdependent RNA polymerase (RdRp). The RdRp of RNA viruses, including EV-A71, shows low fidelity; therefore, replication errors occur with high frequency, resulting in progeny harboring diverse nucleotide substitutions. This diversity of the viral genome allows more adapted variants to replicate selectively and become the dominant species; this process drives the adaptation of viruses to their environment.

\section{Studies on Pathogenicity}

As with many viral infections, some patients become severely ill, whereas others do not; likewise, some epidemics are associated with a high frequency of severe cases, and others are not. Certain factors are thought to be associated with disease severity. Candidates include the environment of the epidemic area (climate, topography, and culture), host factors (susceptibility and immunity), and viral factors (polymorphisms in nucleotides and amino acids). It is not currently clear which of these factors is more critical. However, even though EV-A71 has spread worldwide, outbreaks are sporadic. Although the environment and host factors in an epidemic area do not change over a short period, the genome of RNA viruses changes quickly, so we can assume that mutations in the viral genome are associated with outbreaks. Various attempts have been made to identify the virulence determinants on the EV-A71 genome. However, the virulence determinants currently proposed are not widely accepted by EV-A71 researchers for the following reasons: (1) There are few analyses using virulence evaluation systems that reflect human pathogenesis; (2) EV-A71 can mutate easily in cultured cells and animals and adapt to the given environment. Therefore, it is difficult to distinguish virulence determinants from adaptation determinants. These two factors are discussed in detail below.

\subsection{Evaluation of EV-A71 Virulence}

Evaluation of EV-A71 virulence includes analysis of clinical data from human patients, cynomolgus macaques, suckling mice, immunodeficient mice, and hSCARB2-transgenic (tg) mice. In addition, mouse-adapted strains obtained by repeated passages in mice have been used for virulence study combined with suckling mice or immunodeficient mice. The patient severity approach is performed with the expectation that there will be an association between disease severity in a human patient and the sequence of the viral genome isolated from that patient [25-27]. However, most people infected with EV-A71 have asymptomatic or mild disease, and severe cases are extremely rare; therefore, many 
patients do not become severely ill, even though they are infected with a highly virulent strain. Even if they develop a disease, its severity is influenced by factors, such as the host's genetic background, nutritional status, living environment, and the amount of virus to which they are exposed. Identifying virulence determinants in association studies requires the accumulation of a large amount of data. Alternatively, animal model experiments should be conducted by infecting a relatively large number of animals with large amounts of virus (sufficient to cause apparent disease). In this way, a closer association between disease severity in infected animals and virulence determinants in the viral genome will be demonstrated. EV-A71 infects humans as its natural host, although non-human primates, such as cynomolgus monkeys, can be infected experimentally. When cynomolgus monkeys are intravenously inoculated with EV-A71, they show symptoms, such as paralysis, due to infection of the CNS; however, they do not show skin lesions like HFMD [28]. One caveat to this approach is that although this evaluation system facilitates assessment of the neurovirulence of EV-A71, the availability of experimental facilities for infecting large animals is limited, and the cost per animal and attendant ethical issues make quantitative studies difficult.

Mice are useful model animals because there are fewer problems in terms of equipment, cost, and ethics; also, they are easier to modify genetically. However, there is another problem related to the use of non-primate animal models. EV-A71 cannot use mouse SCARB2 as a receptor [29], and adult mice are not susceptible to infection by EV-A71. However, suckling mice are susceptible within one week of birth; these mice can be used as an animal model for EV-A71 infection [30,31]. Mouse models are important experimental systems that can yield a variety of experimental results. Nevertheless, it is difficult to interpret the data, particularly whether various viral genomic mutations are simply an adaptation to the mouse environment or mutations that increase virulence in humans. Unlike a human disease, EV-A71 intraperitoneally or subcutaneously inoculated to suckling mice mainly targets skeletal muscle, which does not reflect human pathology. In addition, no receptors have been identified for this infection. The immunologically modified mouse strain, AG129, an interferon $\alpha / \beta$ receptor, and interferon $\gamma$ receptor double knockout mouse, is also used for virulence analysis of EV-A71 [32]. AG129 mice are more sensitive to EV-A71 than wild-type mice and are susceptible to infection until two weeks old. The virus replicates mainly in skeletal muscle and then reaches the CNS, resulting in neurological symptoms, such as flaccid paralysis. Studies are conducted in combination with the AG129 mouse model and EV-A71 mouse-adapted strains established by repeated passages in rodent cells or animals $[30,33,34]$. This approach can extend the window of susceptibility by more than six weeks [34].

A tg mouse expressing human SCARB2 can overcome the problems of the above models. EV-A71 can infect hSCARB2-tg mice of any age by intravenous, intraperitoneal, and intracerebral inoculation [35]. CNS neurons are the main target of EV-A71, causing CNS symptoms, such as paralysis, but not causing skin lesions, such as HFMD. Therefore, the hSCARB2-tg mouse is an excellent animal model for CNS disease caused by EV-A71 infection. There are reports of various hSCARB2-tg mice with different promoters and knock-in mice [36-39]. However, the exact differences in susceptibility and infection pathology among these mouse strains are not clearly described [40]. Among these hSCARB2-tg mouse models, hSCARB2-tg mice by Fujii et al. [35] are susceptible to EV-A71 at any age, and the muscle-tropic infection observed in the neonatal period is not observed in adults and is an ideal model for future virulence analysis of EV-A71, as it more closely mimics human pathogenesis and allows for quantitative analysis.

\subsection{HS-Binding Mutations and Tissue Culture Adaptation}

One of the interesting findings related to virulence changes and receptor adaptation is mutations in an HS-binding phenotype. Tan et al. [17,41] found that some mutant strains of EV-A71 can use HS as an attachment receptor. The mutant viruses can bind strongly to HS. The mutations required for the HS-binding phenotype are VP1-E145G or 
E145Q mutation, along with mutations at VP1-97, VP1-98, and VP1-244 [41-43]. These mutations increase the infection efficiency of cultured cells significantly by enhancing virus attachment to the cell surface (Figure 1). Our previous study shows that the virus infection efficiency (copy number $/ 50 \%$ tissue culture infectious dose; $\mathrm{TCID}_{50}$ ) in RD-A cells was 47,619 copies $/$ TCID $_{50}$ for VP1-145E, whereas it was 200 and 100 copies/TCID 50 for VP1-145G and VP1-145Q, respectively [44]. This result means that VP1-145G and VP1-145Q viruses infect RD-A cells 200 times more efficiently than the VP1-145E virus. VP1-145 is located on the particle surface near the 5-fold symmetry axis. This area is positively charged when the amino acid is $\mathrm{G}$ or $\mathrm{Q}$ but less positively charged when the amino acid is $\mathrm{E}$ (this is because the negative charge of the glutamic acid residue cancels the surrounding positive charge) [45]. Since HS is negatively charged by sulfation, it is thought to bind to $G$ and $Q$ particles via electrostatic interactions. Therefore, it is likely that VP1-145G and VP1-145Q viruses infect cultured cells more efficiently than the VP1-145E virus, due to the acquisition of the HS-mediated infection pathway. Other HS-binding mutations around the 5-fold symmetry axis are known [41-43], and may show the same phenotype as VP1-145G and Q. It should be noted that such mutations appear during replication in cultured cells because of the low fidelity of RdRp and that HS-binding mutants are rapidly selected and become predominant in the population under conventional cell culture conditions [44]. Adaptation to cultured cells is thought to occur quickly when an HS-adapted mutant happens to appear as a founder, but if the founder does not appear within the culture period, adaptation does not occur. The emergence of adapted mutants is determined stochastically. Nishimura et al. [45] found that PSGL1 also serves as an attachment receptor in Jurkat cells. Similar mutations of the viral capsid are required for PSGL1-binding because mutant viruses bind to sulfated PSGL1 via electrostatic interactions.

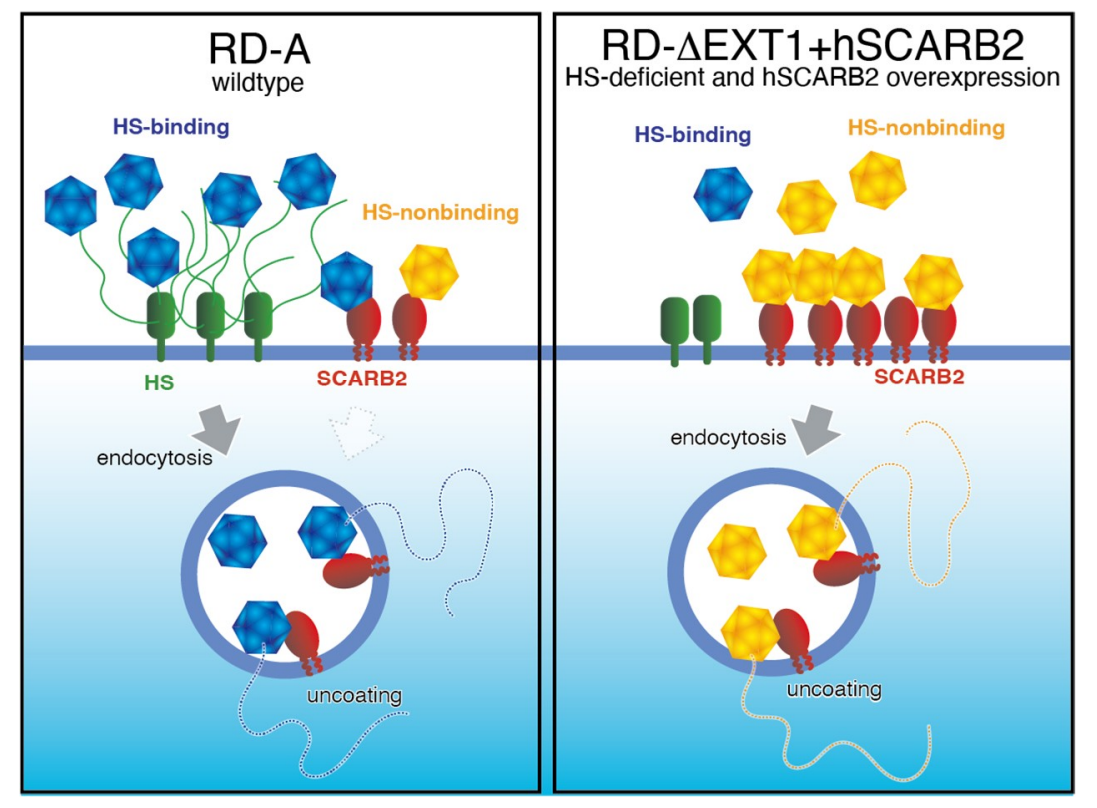

Figure 1. Selective infection of cultured cells by HS-binding mutants. (Left panel) Normal cell lines, such as RD-A, show low cell surface expression of SCARB2 and high expression of HS. Therefore, the infection efficiency of wild-type HS-nonbinding mutants is low. By contrast, a small number of HS-binding mutants emerge during replication and efficiently infect cells through HS; thus, HSbinding mutants become dominant. (Right panel) In RD- $\triangle E X T 1+$ hSCARB2 cells, selective infection by HS-binding mutants is less likely to occur because the expression of SCARB2 and HS, responsible for such infection bias, is optimized.

To better understand the relationship between HS-binding mutations and EV-A71 virulence, we have summarized past papers (see Table 1). The increased infection efficiency of HS-binding strains may increase virulence in vivo. With this in mind, Cordey et al. [46] 
and Tseligka et al. [42] reported the isolation of the VP1-97L mutant from cerebrospinal fluid, stool, and plasma of an immunocompromised patient. The mutation conferred HS-binding ability and a replicative advantage in human neuroblastoma cells. However, more studies are needed to examine the virulence of the isolated virus by some in vivo experimental methods. Analysis of the relationship between disease severity and the viral genome sequence showed that infection by VP1-145G/Q/R was significantly high in severe cases [25-27]. However, the weakness of these reports is that the methods of virus isolation and sequencing are not described. Virus strains isolated from human specimens and grown in conventionally cultured cells undergo a rapid change into HS-binding strains. Further careful analysis is expected to reveal whether HS-binding mutations are associated with virulence in humans.

Table 1. Studies on HS-binding mutations.

\begin{tabular}{|c|c|c|c|c|}
\hline \multirow{2}{*}{$\begin{array}{l}\text { Amino Acid } \\
\text { Position }\end{array}$} & \multicolumn{2}{|c|}{ Amino Acid Residue } & \multirow{2}{*}{ Description } & \multirow{2}{*}{ References } \\
\hline & Virulent & Avirulent & & \\
\hline VP1-145 & G/Q/R & E & $\begin{array}{l}\text { VP1-145G/Q/R was more frequently detected in severe human cases than } \\
\text { VP1-145E. }\end{array}$ & [25] \\
\hline VP1-145 & Q & E & $\begin{array}{l}\text { VP1-145Q was found in two of nine isolates from severe human cases, but all } \\
\text { mild cases were VP1-145E. }\end{array}$ & [26] \\
\hline VP1-145 & Non-E & E & $\begin{array}{l}\text { VP1-145 non-E (the actual amino acid residues are not shown in the paper) was } \\
\text { more frequently detected in HFMD severe cases than VP1-145E. }\end{array}$ & [27] \\
\hline VP1-97 & $\mathrm{R}$ & $\mathrm{L}$ & $\begin{array}{l}\text { VP1-97R was isolated from cerebrospinal fluid, stool, and plasma of an } \\
\text { immunocompromised patient. } \\
\text { VP1-97R conferred a replicative advantage in a human neuroblastoma cell line, } \\
\text { SH-SY5Y. } \\
\text { VP1-97R conferred HS-binding ability. }\end{array}$ & {$[42,46]$} \\
\hline VP1-98 & E & K & $\begin{array}{l}\text { VP1-E98K was acquired by } 30 \text { passages of a mouse-adapted strain in a mouse } \\
\text { cell line, L929. } \\
\text { VP1-E98K conferred a replicative advantage in mouse cell lines L929 and } \\
\text { Neuro2A. } \\
\text { VP1-E98K enhanced binding to HS. } \\
\text { VP1-E98K attenuated the virulence in 2-week-old BALB/c mice. }\end{array}$ & [43] \\
\hline VP1-145 & E & G & $\begin{array}{l}\text { VP1-G145E was acquired by six passages of Chinese Hamster Ovary (CHO) } \\
\text { cells-adapted strain in 1-day-old BALB/c mice. } \\
\text { VP1-G145E enhanced virulence in 1-day-old BALB/c mice. }\end{array}$ & [30] \\
\hline VP1-145 & E & G & $\begin{array}{l}\text { VP1-G145E was acquired by three passages in 3-week-old NOD/SCID mice. } \\
\text { VP1-G145E enhanced virulence in 3-week-old NOD/SCID mice. }\end{array}$ & [47] \\
\hline VP1-145 & E & Q & $\begin{array}{l}\text { VP1-Q145E was introduced in a C4 strain and enhanced virulence in 5-day-old } \\
\text { BALB/c mice. }\end{array}$ & [48] \\
\hline VP1-145 & E & Q & $\begin{array}{l}\text { VP1-Q145E was acquired after four passages in 1-day-old ICR mice. } \\
\text { VP1-Q145E and VP2-K149M co-operatively enhanced virulence in 1-day-old ICR } \\
\text { mice. }\end{array}$ & {$[31,33]$} \\
\hline VP1-145 & E & G & VP1-145E is virulent, but VP1-145G is avirulent in cynomolgus monkeys. & [49] \\
\hline VP1-145 & E & G & $\begin{array}{l}\text { VP1-145G proliferates well in cell lines, such as RD and L-SCARB2, whereas } \\
\text { VP1-145E does not. } \\
\text { VP1-145G binds well to HS, whereas VP1-145E does not. } \\
\text { VP1-145E is virulent, but VP1-145G is avirulent in 6-7-week-old hSCARB2-tg } \\
\text { mice. } \\
\text { VP1-145G is unable to disseminate in the mouse body and reach the CNS. }\end{array}$ & [50] \\
\hline VP1-145 & E & G & $\begin{array}{l}\text { VP1-145E is virulent, but VP1-145G is avirulent in cynomolgus monkeys. } \\
\text { VP1-145G is easily neutralized by antibodies, but VP1-145E is not. }\end{array}$ & [51] \\
\hline $\begin{array}{l}\text { VP1-145 } \\
\text { VP1-244 }\end{array}$ & $\begin{array}{l}\mathrm{E} \\
\mathrm{E}\end{array}$ & $\begin{array}{l}\mathrm{Q} \\
\mathrm{K}\end{array}$ & $\begin{array}{l}\text { VP1-145Q binds well to HS, whereas VP1-145E does not. } \\
\text { VP1-145E is virulent, but VP1-145G is avirulent in 1-day-old ICR mice. } \\
\text { The VP1-K244E mutation was found in the brains of mice infected with } \\
\text { VP1-145Q and was developed (VP1-145Q/244E). } \\
\text { VP1-145Q/244E showed low HS-binding and high mouse virulence. }\end{array}$ & [52] \\
\hline VP1-145 & E & G/Q & $\begin{array}{l}\text { VP1-E145G/Q occurs during growth in cultured cells. } \\
\text { VP1-E145G/Q does not occur when growing in HS-deficient hSCARB2 } \\
\text { overexpressing cells (RD- } \Delta \text { EXT1+hSCARB2). }\end{array}$ & [44] \\
\hline VP1-244 & E & K & $\begin{array}{l}\text { VP1-K244E was detected in a strain that was passaged three times in AG129 mice. } \\
\text { VP1-244E is virulent, but VP1-244K is avirulent in 6-week-old AG129 mice. }\end{array}$ & {$[34,53]$} \\
\hline VP1-244 & E & $\mathrm{K}$ & $\begin{array}{l}\text { VP1-K244E was detected in a strain that was passaged five times in 1-day-old } \\
\text { BALB/c mice. } \\
\text { VP1-244E is virulent, but VP1-244K is avirulent in 5-day-old BALB/c mice. }\end{array}$ & [54] \\
\hline
\end{tabular}


By contrast, many experimental animal studies refute the idea that HS-binding strains are virulent. For example, Chua et al. [30] and Wang et al. [31] used mice to passage EV-A71 strains that are not virulent in mice and obtained strains that caused disease. Chua et al. found that a G to E mutation at VP1-145 (HS-binding to HS-nonbinding mutation) is essential for increased virulence in neonatal mice. Similarly, Wang et al. passaged the 4643 strain in mice and obtained mouse-adapted strain MP4 [31]. By constructing a chimeric virus between 4643 and MP4, Huang et al. [33] found that two mutations co-operatively increased virulence in mice. One of the mutations is VP1-G145E. In addition to VP1-145, other HS-binding mutations associated with EV-A71 attenuation, such as VP1-E98K [43] and VP1-E244K [34,52], are known. All these mutants showed attenuated phenotypes in suckling mice.

Kataoka et al. [49] compared the virulence of PSGL1-binding and -nonbinding strains in cynomolgus monkeys. The PSGL1-binding strains used in this study were also HSbinding strains. The results showed that the PSGL1/HS-binding strains are less virulent than the nonbinding strains; they soon disappeared from the infected monkeys; and were replaced by a nonbinding strain. Similarly, Fujii et al. [51] showed that the HS-nonbinding strain is more virulent than the binding strain. Furthermore, Kobayashi et al. [50] showed a similar result using hSCARB2-tg mice. Thus, HS-nonbinding strains are more virulent than HS-binding strains. Viruses converted to HS-nonbinding strains were recovered from the CNS of paralyzed mice inoculated with a high dose of an HS-binding strain. The authors proposed the following hypothesis: In hSCARB2-tg mice and cynomolgus monkeys (and probably in other animals), cells expressing HS at very high levels (e.g., vascular endothelial cells, sinusoidal endothelial cells, and glomeruli) do not express SCARB2, whereas cells expressing SCARB2 (e.g., neurons, hepatocytes, and tubular epithelial cells) do not express HS $[50,51]$. HS is also present in the extracellular matrix. HS-binding viruses cannot infect their primary target cells in this situation because extracellular matrices and cells that do not express SCARB2 adsorb the HS-binding viruses [50]. Therefore, unlike cultured cells in vitro, HS does not support virus replication in vivo. Instead, it inhibits the dissemination of the virus by adsorbing the viruses. Tee et al. [52] also observed a similar adsorption phenomenon in suckling mice infected with EV-A71 possessing HS-binding amino acids at VP1-145 and VP1-244. In addition, an adsorption phenomenon was reported in an EV-A71 strain carrying the mutation VP1-E98K [43]. Therefore, any amino acid mutation in the HS-binding type is likely to reduce the virulence of EV-A71 in animal models.

\subsection{Mouse (Rodent) Adaptation}

Except for hSCARB2-tg mice, infection with most EV-A71 wild-type strains is limited to suckling mice aged up to 1 week. Some research groups have tried to increase virulence in mice to elucidate the mechanisms underlying increased virulence in mice and humans. We have collected studies reporting mouse adaptation and listed them in Table 2. Chua et al. [30] and Wang et al. [31] identified mutations at VP2-149 that increased virulence in suckling mice. They found that the VP2-149 mutation K to I or M, and the VP1-145 mutation $\mathrm{G}$ to $\mathrm{E}$, co-operatively contribute to disease. There are also reports of isolating the VP2-149I virus, a highly virulent strain in mice, from human samples without mouse adaptation [55]. This result suggests that the VP2-149I mutant is circulating in humans at a low frequency. It is unclear from these in vivo results whether these mutants merely adapted in mice or whether they show increased virulence in mice and humans. 
Table 2. Studies on mouse adaptation.

\begin{tabular}{|c|c|c|c|c|c|}
\hline $\begin{array}{c}\text { Mouse } \\
\text { Adaptation } \\
\text { Mutation }\end{array}$ & $\begin{array}{l}\text { Adapted } \\
\text { Strain }\end{array}$ & $\begin{array}{l}\text { Adaptation } \\
\text { Procedure }\end{array}$ & $\begin{array}{l}\text { Replication in } \\
\text { Cell Lines }\end{array}$ & $\begin{array}{l}\text { Virulence in } \\
\text { an Animal } \\
\text { Model }\end{array}$ & References \\
\hline VP2-K149M & MP4 & $\begin{array}{l}\text { Four passages } \\
\text { in 1-day-old } \\
\text { ICR mice }\end{array}$ & $\begin{array}{c}\text { MP4 is highly } \\
\text { proliferative in } \\
\text { several human cell } \\
\text { lines }\end{array}$ & $\begin{array}{c}\mathrm{VP} 2-\mathrm{K} 149 \mathrm{M} \\
\text { and } \\
\text { VP1-Q145E are } \\
\text { together } \\
\text { responsible for } \\
\text { mouse } \\
\text { virulence }\end{array}$ & {$[31,33]$} \\
\hline VP2-K149I & $\begin{array}{l}\text { CHO-26M } \\
\text { MP-26M }\end{array}$ & $\begin{array}{c}\text { Six passages in } \\
\text { a hamster cell } \\
\text { line }(\mathrm{CHO}), \\
\text { then } \mathrm{f} \\
\text { our passages in } \\
\text { suckling mice }\end{array}$ & NT & $\begin{array}{l}\text { VP2-K149I did } \\
\text { not contribute } \\
\text { much, and } \\
\text { VP1-G145E } \\
\text { was the most } \\
\text { critical } \\
\text { mutation }\end{array}$ & [30] \\
\hline $\begin{array}{l}\text { VP2-K149I } \\
\text { VP2-K149M }\end{array}$ & $\begin{array}{c}\text { 1095-LPS1 } \\
\text { SK-EV006- } \\
\text { LPS1 } \\
\text { C7/Osaka- } \\
\text { LPS1 } \\
\text { 75-Yamagata- } \\
\text { LPS1 }\end{array}$ & $\begin{array}{l}\text { One passage in } \\
\text { a human } \\
\text { PSGL1 } \\
\text { overexpressing } \\
\text { mouse cell line } \\
\text { (L-PSGL1) }\end{array}$ & $\begin{array}{l}\text { Adaptation } \\
\text { increased } \\
\text { proliferation in } \\
\text { L-PSGL1 }\end{array}$ & NT & [56] \\
\hline $\begin{array}{l}\text { VP2-K149I } \\
\text { VP2-K149M }\end{array}$ & $\begin{array}{l}\mathrm{CHO}-\mathrm{B} 5 \\
\mathrm{CHO}-\mathrm{C} 2\end{array}$ & $\begin{array}{c}\text { Four to eight } \\
\text { passages in a } \\
\text { hamster cell } \\
\text { line }(\mathrm{CHO})\end{array}$ & $\begin{array}{l}\text { CHO-B5, CHO-C4, } \\
\text { and the parental } \\
\text { strains containing } \\
\text { VP2-K149I or } \\
\text { VP2-K149M } \\
\text { showed enhanced } \\
\text { proliferation in } \\
\text { CHO cells. All of } \\
\text { these viruses are } \\
\text { VP1-145Q } \\
\text { (HS-binding) }\end{array}$ & NT & [48] \\
\hline VP2-K149I & $\begin{array}{l}\text { EV71:TLLm } \\
\text { EV71:TLLmv }\end{array}$ & $\begin{array}{c}60 \text { and } 100 \\
\text { passages in a } \\
\text { mouse cell line } \\
(\mathrm{NIH} / 3 \mathrm{~T} 3)\end{array}$ & $\begin{array}{l}\text { TLLm and TLLmV } \\
\text { show increased } \\
\text { efficiency for } \\
\text { infecting various } \\
\text { rodent cell lines, } \\
\text { but the VP2-K149I } \\
\text { point mutant does } \\
\text { not show the same } \\
\text { increase in } \\
\text { infection in such } \\
\text { cells. The reason } \\
\text { for this may be that } \\
\text { the strains used are } \\
\text { HS-nonbinding }\end{array}$ & $\begin{array}{l}\text { No increase in } \\
\text { virulence was } \\
\text { observed with } \\
\text { VP2-K149I }\end{array}$ & {$[57,58]$} \\
\hline VP2-K149I & GZ-CII & $\begin{array}{c}\text { VP2-149I have } \\
\text { been isolated } \\
\text { from a human } \\
\text { patient }\end{array}$ & NT & $\begin{array}{c}\text { GZ-CII and } \\
\text { artificially } \\
\text { mutated } \\
\text { VP2-K149I } \\
\text { viruses are } \\
\text { highly virulent } \\
\text { in mice }\end{array}$ & [55] \\
\hline
\end{tabular}

NT: not tested.

EV-A71 naturally infects and replicates in human cells, but the infection efficiency in mouse cells is extremely low because EV-A71 cannot use mouse SCARB2 as a receptor [29]. Therefore, attempts have been made to grow the EV-A71 strains in rodent cells. Chua et al. [30], Victorio et al. [57], and Zaini et al. [48] showed independently that adapted mutants could be obtained by serial passage in hamster or mouse cell lines. The mutants contained the VP2-K149I or VP2-K149M mutation. These mutations increase infectivity and proliferation in mouse and hamster cell lines [48,57]. Therefore, these mutations are considered to be the result of rodent adaptation.

In addition, Miyamura et al. [56] performed an interesting adaptation experiment. Mouse L929 cells overexpressing PSGL1 (L-PSGL1) are not fully susceptible to EV-A71 (PSGL1-binding strain), and the viruses replicate very slowly. They obtained mutant strains adapted to L-PSGL1 cells by passaging five different PSGL1-binding strains for one generation in L-PSGL1 cells. As a result, they obtained adapted strains that replicate 
with normal kinetics, four strains with the VP2-149 mutation, and one strain without the VP2-149 mutation. Since PSGL1 is an attachment receptor that cannot initiate the uncoating reaction, the mutation at VP2-149 is thought to enhance the uncoating reaction in rodent cells. Co-crystallographic analysis of EV-A71 and human SCARB2 revealed hydrophobic interactions between VP2-149 and four residues on SCARB2 alpha helix 5: 158A, 159M, 162A, and 163Y (Figure 2) [15]. At that region, the sequence of human and mouse SCARB2 is most divergent [29]. The result suggested that the amino acid mutation at VP2-149 is associated with altered receptor usage and the acquisition of uncoating activity in rodent cells.

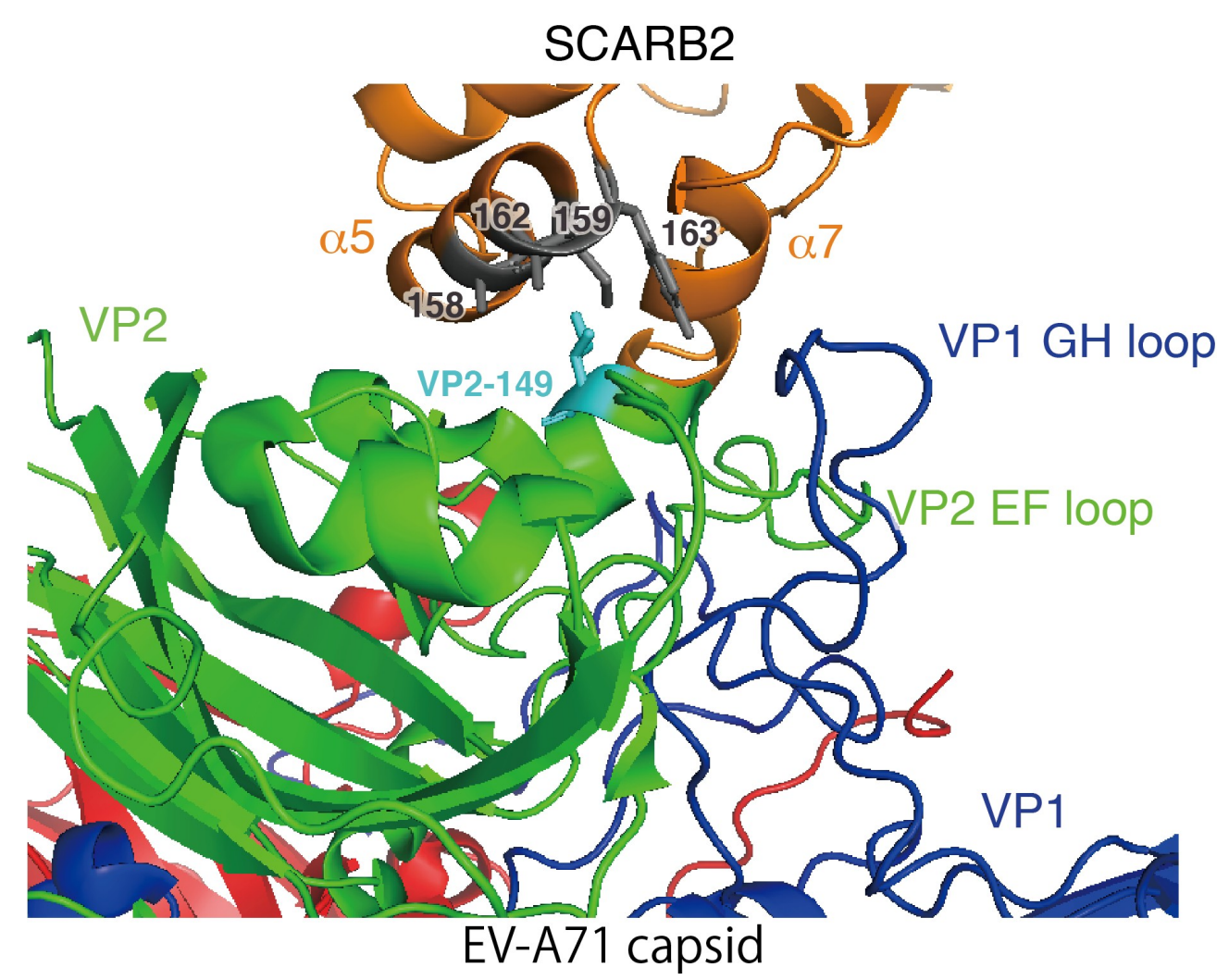

Figure 2. The binding site of VP2-149 and hSCARB2. The 3D structure of the EV-A71 capsid protomer (VP1, VP2, and VP3 in blue, green, and red, respectively) and the ectodomain of hSCARB2 (orange) are shown in cartoon representation. VP2-149 is shown as a cyan stick, and hSCARB2 residues 158A, 159M, 162A, and 163Y are shown as gray sticks. This figure was produced using Protein Data Base 6I2K.

Besides the mutation at VP2-149 described above, Victorio et al. [58] reported that VP1K98E, E145A, and L169F use mouse SCARB2. Interestingly, a single amino acid mutation in VP1-L169F gives it infectivity in a mouse cell line. Although these amino acids are not directly binding sites for SCARB2 [15], these changes may indirectly affect the binding to mouse SCARB2. However, little analysis of this amino acid has been done by other groups, and further analysis is required. Miyamura et al. [56] also obtained a mutant adapted to L-PSGL1 cells without the VP1-K149I mutation. This mutant contained VP2-K69R, VP2-V135I, VP2-T176P, VP1-X145Q (where X is a mixture of two or more amino acids), and VP1-I249V. Rodent adaptation may occur in several different mechanisms.

It is unclear whether this mutation allows mouse or hamster SCARB2 to be used as an uncoating receptor or allows other receptors to be used. However, clarifying the molecular mechanism by which this amino acid mutation alters the properties of the virus particle and why it can infect mice makes a significant contribution to clarifying some of the factors necessary for the virulence of EV-A71. It is important to remember that this mutation is 
likely an adaptation determinant, not a virulence determinant. However, further studies should examine whether this mutation explains the severity of the disease in humans.

Figure 3 combines the results of VP1 and VP2 mutations. The interpretation of some original articles is confusing and misleading. However, it is possible to interpret the results from two axes. One axis comprises mutations controlling the HS-binding phenotype. HSbinding and HS-nonbinding phenotypes are associated with in vitro cell culture adaptation and in vivo adaptation, respectively. HS-binding strains grow more efficiently in cultured cells, but HS-nonbinding strains replicate more efficiently in an animal body and cause severe disease. The other axis is the host range-affecting mutation at VP2-149. VP2-149I/M mutants can infect rodents, probably using the mouse SCARB2 protein as an uncoating receptor (though it has not been demonstrated). It has not been proven whether the VP2-149 mutation is virulent in humans.

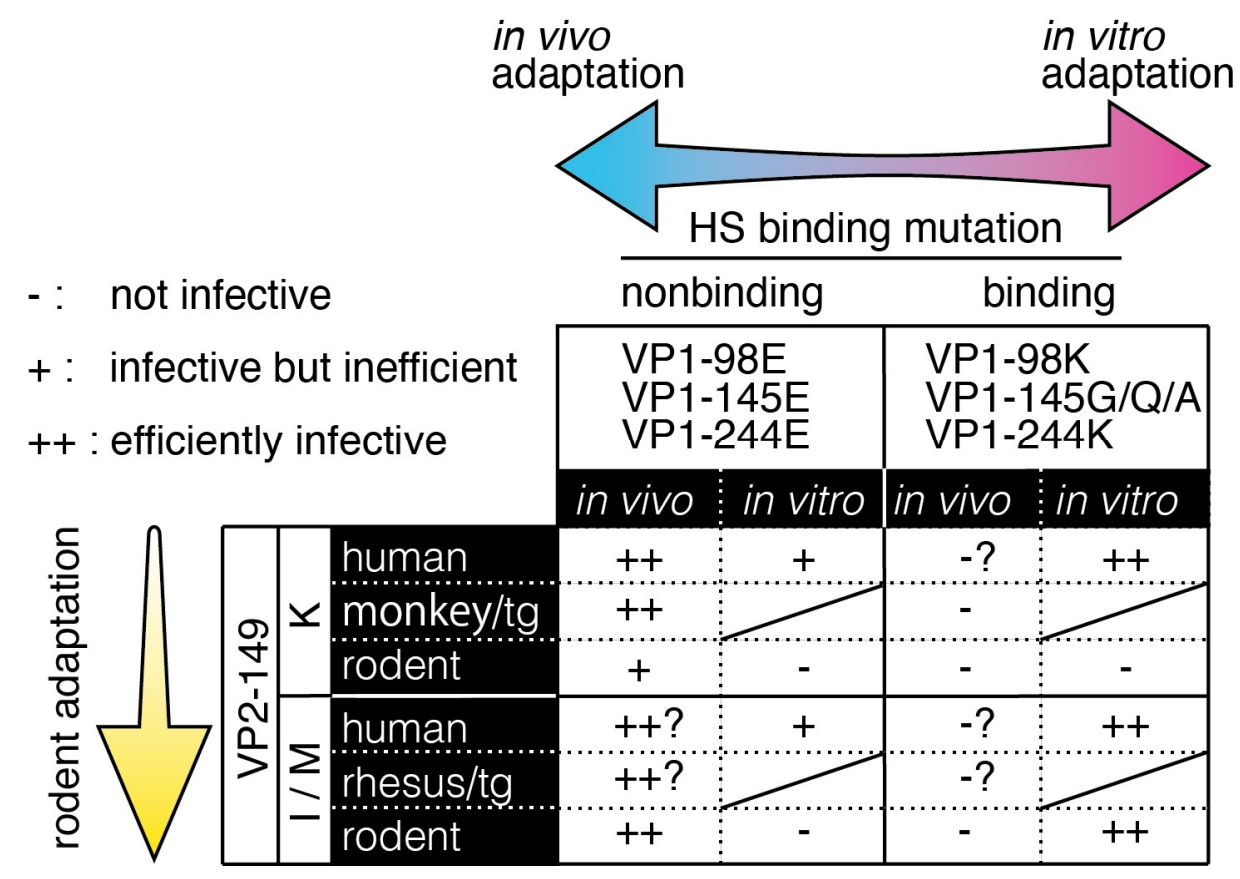

Figure 3. The HS-binding mutation controls in vitro (cultured cells) and in vivo adaptations, whereas the VP2-149 mutation controls adaptation to rodents. Human/in vivo indicates infection of human patients, human/in vitro indicates infection of human-derived cell lines, monkey/ $\mathrm{tg} / \mathrm{in}$ vivo indicates infection of cynomolgus monkeys and hSCARB2-tg mice, rodent/in vivo indicates infection of suckling mice, and rodent/in vitro indicates infection of rodent cell lines.

\subsection{Possible Neurovirulence Determinants Not Influenced by Adaptation Mutations}

So far, we have discussed mutations involved in the adaptation of cultured cells and mice; however, there are also reports of virulence determinants that are not related to these mutations. They can be classified into mutations associated with the fidelity of viral RdRp, mutations related to temperature sensitivity $(t s)$, and mutations that do not belong to any of these categories. The former two were produced artificially. These attempts may be important for developing live attenuated vaccines. The third appeared spontaneously in a human patient. Here, we discuss how these mutations affect EV-A71 virulence.

As mentioned already, the fidelity of RNA virus RdRp is low. However, poliovirus $(\mathrm{PV})$ research revealed that 3D-G64S is an amino acid mutation that increases fidelity. This mutation reduces PV virulence [59-61]. Meng and Kwang showed an association between EV-A71 virulence and RdRp fidelity [62]. They cultured EV-A71 in the presence of ribavirin, a mutagenic reagent, and obtained ribavirin-resistant EV-A71 mutants. The mutant acquired the 3D-L123F mutation, which increases the replication fidelity of the RdRp. They also produced various 3D-64 mutants based on the PV study and identified 
3D-G64R as a viable mutant; they showed that this mutation contributed to the increase in replication fidelity. In addition, the G64R and L123F double mutant showed even greater replication fidelity. The L123F mutation showed a reduced growth rate in cultured cells, but G64R was comparable to the wild type. When these single and double mutants were inoculated into AG129 mice and tested for virulence, all were less virulent than the wild type, with the double mutant being the weakest. The results show that increased replication fidelity reduces the virulence of EV-A71, which is consistent with the report for PV.

Ts is an essential phenotype of live attenuated PV vaccine strains (Sabin 1, 2, and $3)$, which prevents the virus from replicating at high temperatures $\left(38-40^{\circ} \mathrm{C}\right)$. Mutations in the PV genome associated with ts exist across multiple locations [63]. Several reports have examined ts mutations in EV-A71. Arita et al. [64] compared the sequence of $t s$ with that of temperature-resistant mutants of the EV-A71 reference strain, $\mathrm{BrCr}$, and found a 9-nucleotide mismatch. When analyzing these mutant viruses, they found that VP1-Y116H was associated with $t$ s. In addition, using known nucleotide and amino acid mutations that define the difference in virulence between the virulent strains of PV1 Mahoney and the attenuated strain Sabin1, they found that mutations in 5'-UTR-485, 3D-73, 3D-363, and $3^{\prime}$-UTR-7409 make a combined contribution to $t$. In addition, these ts-mutant strains show reduced virulence in cynomolgus monkeys. In addition, Kung et al. [65] showed that 3D-251 plays an important role in the ts of EV-A71. Both the 3D-251I and T mutants showed similar growth at $35^{\circ} \mathrm{C}$, but at $39^{\circ} \mathrm{C}$, the growth rate of $3 \mathrm{D}-251 \mathrm{~T}$ was reduced markedly, with a slight decrease in virulence in suckling mice.

The mutations mentioned so far allow us to estimate the underlying mechanism for changes in virus properties. However, the following mutations are also interesting, although the putative mechanism(s) is unknown. Huang et al. [66] performed a haplotype analysis of viral genomes in various organs of a fatal case of EV-A71 infection. The genetic diversity of EV-A71 in the respiratory and gastrointestinal tract lumens was extremely high, but specific haplotypes were selected to replicate in the CNS. Only VP1-D31G was a positively selected amino acid mutation in CNS. In vitro analysis showed that VP1-31G particles were less stable than VP1-31D particles and showed high proliferation in neuronderived cell lines. This result suggests that viruses that spread from human to human and viruses that reach the CNS after infecting humans have different genetic characteristics. However, the difference in neurovirulence has not been verified in animal experiments. More detailed analysis of this amino acid mutation and more clinical data are needed to support it.

\section{Identification of True Virulence Determinants}

As we described above, the systems used to evaluate the virulence of EV-A71 have many problems. When a virus from a human clinical specimen is transferred to RDA and Vero cells, both of which are used widely for EV-A71 culture, mutations of the HS-binding phenotype occur with a high frequency and are strongly selected [44]. To identify the true virulence determinants of EV-A71, we need to optimize virus isolation and propagation methods, as well as virulence evaluation methods. Therefore, we established a cell line, RD- $\triangle \mathrm{EXT1+hSCARB2,} \mathrm{lacking} \mathrm{an} \mathrm{enzyme} \mathrm{involved} \mathrm{in} \mathrm{HS} \mathrm{biosynthesis} \mathrm{(exostosin}$ glycosyltransferase 1) and overexpressing human SCARB2. In this cell line, the selection of HS-binding strains can be minimized (Figure 1). Since even contamination of a virus sample with a small amount of HS-binding mutant can affect the viral titer significantly, the virus stock used in the experiment should be verified for the presence of HS-binding mutations using a next-generation sequencer. To the best of our knowledge, the best model for evaluating viral virulence is the hSCARB2-tg mouse, which shows very similar neurological symptoms to humans. This method allows the evaluation of clinically isolated strains without any bias for host range adaptation and enables the use of sufficient mice for quantitative analysis.

We would like to introduce the virulence evaluation experiments we have conducted recently, following this analysis flow [67]. We conducted an epidemiological study of the 
HFMD epidemic in Vietnam in 2015-2016. The results showed that EV-A71 was prevalent in subgenogroups B5 and C4 simultaneously and that the severity (hospitalization rate) was higher in patients infected with C4. To confirm this experimentally, we isolated the virus by infecting EV-A71-positive patient specimens (pharyngeal or rectal swabs) with $\mathrm{RD}-\triangle \mathrm{EXT} 1+\mathrm{hSCARB} 2$. After conducting next-generation sequencing to confirm that none of the strains used in the infection experiments contained all known HS-binding and mouse-adapted mutations, the viral titer $\left(\mathrm{TCID}_{50}\right)$ was quantitated using RD-A cells. The 6-7-week-old hSCARB2-tg mice were inoculated intraperitoneally with the isolated strains $\left(500,000 \mathrm{TCID}_{50} /\right.$ mouse) and were evaluated for CNS symptoms (paralysis of limbs) and mortality. The results showed that $\mathrm{C} 4$ was more virulent, as was the patient hospitalization rate. By following this flow, it is possible to perform virulence analysis using a system that mimics human pathology while maintaining the viral genome sequence in the patient. We also propose defining the viral dose for inoculation by RNA copy number or the number of infectious particles. In this case, one can avoid the problem that the relative titer of inoculation virus varies depending on the cell lines used for titration. Further studies based on carefully selected examination systems should identify virulence determinants of EV-A71 in the future.

Author Contributions: Conceptualization, S.K. and K.K.; writing—review and editing, K.K.; visualization, K.K.; supervision, S.K.; funding acquisition, S.K. and K.K. All authors have read and agreed to the published version of the manuscript.

Funding: This work was supported by JSPS KAKENHI (grant number 19K07601 for KK) and by AMED (grant number 21fk0108084h1203 for SK).

Conflicts of Interest: The authors declare no conflict of interest.

\section{References}

1. Herrero, L.J.; Lee, C.S.; Hurrelbrink, R.J.; Chua, B.H.; Chua, K.B.; McMinn, P.C. Molecular epidemiology of enterovirus 71 in peninsular Malaysia, 1997-2000. Arch. Virol. 2003, 148, 1369-1385. [CrossRef] [PubMed]

2. Chan, L.G.; Parashar, U.D.; Lye, M.S.; Ong, F.G.; Zaki, S.R.; Alexander, J.P.; Ho, K.K.; Han, L.L.; Pallansch, M.A.; Suleiman, A.B.; et al. Deaths of children during an outbreak of hand, foot, and mouth disease in sarawak, malaysia: Clinical and pathological characteristics of the disease. For the Outbreak Study Group. Clin. Infect. Dis. 2000, 31, 678-683. [CrossRef] [PubMed]

3. Chang, L.Y.; Lin, T.Y.; Hsu, K.H.; Huang, Y.C.; Lin, K.L.; Hsueh, C.; Shih, S.R.; Ning, H.C.; Hwang, M.S.; Wang, H.S.; et al. Clinical features and risk factors of pulmonary oedema after enterovirus-71-related hand, foot, and mouth disease. Lancet 1999, 354, 1682-1686. [CrossRef]

4. Shih, S.R.; Ho, M.S.; Lin, K.H.; Wu, S.L.; Chen, Y.T.; Wu, C.N.; Lin, T.Y.; Chang, L.Y.; Tsao, K.C.; Ning, H.C.; et al. Genetic analysis of enterovirus 71 isolated from fatal and non-fatal cases of hand, foot and mouth disease during an epidemic in Taiwan, 1998. Virus Res. 2000, 68, 127-136. [CrossRef]

5. Ho, M.; Chen, E.R.; Hsu, K.H.; Twu, S.J.; Chen, K.T.; Tsai, S.F.; Wang, J.R.; Shih, S.R. An epidemic of enterovirus 71 infection in Taiwan. Taiwan Enterovirus Epidemic Working Group. N. Engl. J. Med. 1999, 341, 929-935. [CrossRef] [PubMed]

6. Chen, S.C.; Chang, H.L.; Yan, T.R.; Cheng, Y.T.; Chen, K.T. An eight-year study of epidemiologic features of enterovirus 71 infection in Taiwan. Am. J. Trop. Med. Hyg. 2007, 77, 188-191. [CrossRef] [PubMed]

7. Lin, K.H.; Hwang, K.P.; Ke, G.M.; Wang, C.F.; Ke, L.Y.; Hsu, Y.T.; Tung, Y.C.; Chu, P.Y.; Chen, B.H.; Chen, H.L.; et al. Evolution of EV71 genogroup in Taiwan from 1998 to 2005: An emerging of subgenogroup C4 of EV71. J. Med. Virol. 2006, 78, 254-262. [CrossRef] [PubMed]

8. Fu, X.; Wan, Z.; Li, Y.; Hu, Y.; Jin, X.; Zhang, C. National Epidemiology and Evolutionary History of Four Hand, Foot and Mouth Disease-Related Enteroviruses in China from 2008 to 2016. Virol. Sin. 2020, 35, 21-33. [CrossRef] [PubMed]

9. Khanh, T.H.; Sabanathan, S.; Thanh, T.T.; Thoa, L.P.K.; Thuong, T.C.; Hang, V.; Farrar, J.; Hien, T.T.; Chau, N.; van Doorn, H.R. Enterovirus 71-associated hand, foot, and mouth disease, Southern Vietnam, 2011. Emerg. Infect. Dis. 2012, 18, 2002-2005. [CrossRef]

10. Seiff, A. Cambodia unravels cause of mystery illness. Lancet 2012, 380, 206. [CrossRef]

11. Duong, V.; Mey, C.; Eloit, M.; Zhu, H.; Danet, L.; Huang, Z.; Zou, G.; Tarantola, A.; Cheval, J.; Perot, P.; et al. Molecular epidemiology of human enterovirus 71 at the origin of an epidemic of fatal hand, foot and mouth disease cases in Cambodia. Emerg. Microbes Infect. 2016, 5, e104. [CrossRef] [PubMed]

12. Racaniello, V. Picornaviridae: The Viruses and Their Replication. In Fields Virology, 6th ed.; Knipe, D., Howley, P.M., Eds.; Wolters Kluwer Health/Lippincott Williams \& Wilkins: Philadelphia, PA, USA, 2013; pp. 453-489. 
13. Yamayoshi, S.; Yamashita, Y.; Li, J.; Hanagata, N.; Minowa, T.; Takemura, T.; Koike, S. Scavenger receptor B2 is a cellular receptor for enterovirus 71. Nat. Med. 2009, 15, 798-801. [CrossRef] [PubMed]

14. Yamayoshi, S.; Ohka, S.; Fujii, K.; Koike, S. Functional comparison of SCARB2 and PSGL1 as receptors for enterovirus 71. J. Virol. 2013, 87, 3335-3347. [CrossRef] [PubMed]

15. Zhou, D.; Zhao, Y.; Kotecha, A.; Fry, E.E.; Kelly, J.T.; Wang, X.; Rao, Z.; Rowlands, D.J.; Ren, J.; Stuart, D.I. Unexpected mode of engagement between enterovirus 71 and its receptor SCARB2. Nat. Microbiol. 2019, 4, 414-419. [CrossRef]

16. Nishimura, Y.; Shimojima, M.; Tano, Y.; Miyamura, T.; Wakita, T.; Shimizu, H. Human P-selectin glycoprotein ligand-1 is a functional receptor for enterovirus 71. Nat. Med. 2009, 15, 794-797. [CrossRef]

17. Tan, C.W.; Poh, C.L.; Sam, I.C.; Chan, Y.F. Enterovirus 71 uses cell surface heparan sulfate glycosaminoglycan as an attachment receptor. J. Virol. 2013, 87, 611-620. [CrossRef]

18. Su, P.Y.; Liu, Y.T.; Chang, H.Y.; Huang, S.W.; Wang, Y.F.; Yu, C.K.; Wang, J.R.; Chang, C.F. Cell surface sialylation affects binding of enterovirus 71 to rhabdomyosarcoma and neuroblastoma cells. BMC Microbiol. 2012, 12, 162. [CrossRef]

19. Yang, S.L.; Chou, Y.T.; Wu, C.N.; Ho, M.S. Annexin II Binds to Capsid Protein VP1 of Enterovirus 71 and Enhances Viral Infectivity. J. Virol. 2011, 85, 11809-11820. [CrossRef]

20. Su, P.Y.; Wang, Y.F.; Huang, S.W.; Lo, Y.C.; Wang, Y.H.; Wu, S.R.; Shieh, D.B.; Chen, S.H.; Wang, J.R.; Lai, M.D.; et al. Cell surface nucleolin facilitates enterovirus 71 binding and infection. J. Virol. 2015, 89, 4527-4538. [CrossRef]

21. Du, N.; Cong, H.; Tian, H.; Zhang, H.; Zhang, W.; Song, L.; Tien, P. Cell surface vimentin is an attachment receptor for enterovirus 71. J. Virol. 2014, 88, 5816-5833. [CrossRef]

22. He, Q.Q.; Ren, S.; Xia, Z.C.; Cheng, Z.K.; Peng, N.F.; Zhu, Y. Fibronectin Facilitates Enterovirus 71 Infection by Mediating Viral Entry. J. Virol. 2018, 92, e02251-17. [CrossRef]

23. Sarrazin, S.; Lamanna, W.C.; Esko, J.D. Heparan sulfate proteoglycans. Cold Spring Harb. Perspect. Biol. 2011,3 , a004952. [CrossRef]

24. Nishimura, Y.; Wakita, T.; Shimizu, H. Tyrosine sulfation of the amino terminus of PSGL-1 is critical for enterovirus 71 infection. PLoS Pathog. 2010, 6, e1001174. [CrossRef]

25. Li, R.; Zou, Q.; Chen, L.; Zhang, H.; Wang, Y. Molecular analysis of virulent determinants of enterovirus 71. PLoS ONE 2011, 6 , e26237. [CrossRef]

26. Chang, S.C.; Li, W.C.; Chen, G.W.; Tsao, K.C.; Huang, C.G.; Huang, Y.C.; Chiu, C.H.; Kuo, C.Y.; Tsai, K.N.; Shih, S.R.; et al. Genetic characterization of enterovirus 71 isolated from patients with severe disease by comparative analysis of complete genomes. $J$. Med. Virol. 2012, 84, 931-939. [CrossRef] [PubMed]

27. Chang, C.-S.; Liao, C.-C.; Liou, A.-T.; Chou, Y.-C.; Yu, Y.-Y.; Lin, C.-Y.; Lin, J.-S.; Suen, C.-S.; Hwang, M.-J.; Shih, C. Novel Naturally Occurring Mutations of Enterovirus 71 Associated With Disease Severity. Front. Microbiol. 2021, 11, 3535. [CrossRef] [PubMed]

28. Nagata, N.; Shimizu, H.; Ami, Y.; Tano, Y.; Harashima, A.; Suzaki, Y.; Sato, Y.; Miyamura, T.; Sata, T.; Iwasaki, T. Pyramidal and extrapyramidal involvement in experimental infection of cynomolgus monkeys with enterovirus 71. J. Med. Virol. 2002, 67, 207-216. [CrossRef] [PubMed]

29. Yamayoshi, S.; Koike, S. Identification of a human SCARB2 region that is important for enterovirus 71 binding and infection. $J$. Virol. 2011, 85, 4937-4946. [CrossRef] [PubMed]

30. Chua, B.H.; Phuektes, P.; Sanders, S.A.; Nicholls, P.K.; McMinn, P.C. The molecular basis of mouse adaptation by human enterovirus 71. J. Gen. Virol. 2008, 89, 1622-1632. [CrossRef]

31. Wang, Y.F.; Chou, C.T.; Lei, H.Y.; Liu, C.C.; Wang, S.M.; Yan, J.J.; Su, I.J.; Wang, J.R.; Yeh, T.M.; Chen, S.H.; et al. A mouse-adapted enterovirus 71 strain causes neurological disease in mice after oral infection. J. Virol. 2004, 78, 7916-7924. [CrossRef]

32. Khong, W.X.; Yan, B.; Yeo, H.; Tan, E.L.; Lee, J.J.; Ng, J.K.; Chow, V.T.; Alonso, S. A non-mouse-adapted enterovirus 71 (EV71) strain exhibits neurotropism, causing neurological manifestations in a novel mouse model of EV71 infection. J. Virol. 2012, 86, 2121-2131. [CrossRef] [PubMed]

33. Caine, E.A.; Moncla, L.H.; Ronderos, M.D.; Friedrich, T.C.; Osorio, J.E.; López, S. A Single Mutation in the VP1 of Enterovirus 71 Is Responsible for Increased Virulence and Neurotropism in Adult Interferon-Deficient Mice. J. Virol. 2016, 90, 8592-8604. [CrossRef]

34. Huang, S.W.; Wang, Y.F.; Yu, C.K.; Su, I.J.; Wang, J.R. Mutations in VP2 and VP1 capsid proteins increase infectivity and mouse lethality of enterovirus 71 by virus binding and RNA accumulation enhancement. Virology 2012, 422, 132-143. [CrossRef]

35. Fujii, K.; Nagata, N.; Sato, Y.; Ong, K.C.; Wong, K.T.; Yamayoshi, S.; Shimanuki, M.; Shitara, H.; Taya, C.; Koike, S. Transgenic mouse model for the study of enterovirus 71 neuropathogenesis. Proc. Natl. Acad. Sci. USA 2013, 110, 14753-14758. [CrossRef] [PubMed]

36. Lin, Y.W.; Yu, S.L.; Shao, H.Y.; Lin, H.Y.; Liu, C.C.; Hsiao, K.N.; Chitra, E.; Tsou, Y.L.; Chang, H.W.; Sia, C.; et al. Human SCARB2 transgenic mice as an infectious animal model for enterovirus 71. PLoS ONE 2013, 8, e57591. [CrossRef]

37. Yang, C.H.; Liang, C.T.; Jiang, S.T.; Chen, K.H.; Yang, C.C.; Cheng, M.L.; Ho, H.Y. A Novel Murine Model Expressing a Chimeric mSCARB2/hSCARB2 Receptor Is Highly Susceptible to Oral Infection with Clinical Isolates of Enterovirus 71. J. Virol. 2019, 93. [CrossRef]

38. Zhou, S.; Liu, Q.; Wu, X.; Chen, P.; Wu, X.; Guo, Y.; Liu, S.; Liang, Z.; Fan, C.; Wang, Y. A safe and sensitive enterovirus A71 infection model based on human SCARB2 knock-in mice. Vaccine 2016, 34, 2729-2736. [CrossRef] 
39. Zhu, J.; Chen, N.; Zhou, S.; Zheng, K.; Sun, L.; Zhang, Y.; Cao, L.; Zhang, X.; Xiang, Q.; Chen, Z.; et al. Severity of enterovirus A71 infection in a human SCARB2 knock-in mouse model is dependent on infectious strain and route. Emerg. Microbes Infect. 2018, 7, 205. [CrossRef] [PubMed]

40. Kobayashi, K.; Koike, S. Cellular receptors for enterovirus A71. J. Biomed. Sci. 2020, 27, 23. [CrossRef]

41. Tan, C.W.; Sam, I.C.; Lee, V.S.; Wong, H.V.; Chan, Y.F. VP1 residues around the five-fold axis of enterovirus A71 mediate heparan sulfate interaction. Virology 2017, 501, 79-87. [CrossRef] [PubMed]

42. Tseligka, E.D.; Sobo, K.; Stoppini, L.; Cagno, V.; Abdul, F.; Piuz, I.; Meylan, P.; Huang, S.; Constant, S.; Tapparel, C. A VP1 mutation acquired during an enterovirus 71 disseminated infection confers heparan sulfate binding ability and modulates ex vivo tropism. PLoS Pathog. 2018, 14, e1007190. [CrossRef]

43. Ke, X.; Zhang, Y.; Liu, Y.; Miao, Y.; Zheng, C.; Luo, D.; Sun, J.; Hu, Q.; Xu, Y.; Wang, H.; et al. A Single Mutation in the VP1 Gene of Enterovirus 71 Enhances Viral Binding to Heparan Sulfate and Impairs Viral Pathogenicity in Mice. Viruses 2020, 12, 883. [CrossRef]

44. Kobayashi, K.; Mizuta, K.; Koike, S. Heparan sulfate attachment receptor is a major selection factor for attenuated enterovirus 71 mutants during cell culture adaptation. PLoS Pathog. 2020, 16, e1008428. [CrossRef] [PubMed]

45. Nishimura, Y.; Lee, H.; Hafenstein, S.; Kataoka, C.; Wakita, T.; Bergelson, J.M.; Shimizu, H. Enterovirus 71 binding to PSGL-1 on leukocytes: VP1-145 acts as a molecular switch to control receptor interaction. PLoS Pathog. 2013, 9, e1003511. [CrossRef]

46. Cordey, S.; Petty, T.J.; Schibler, M.; Martinez, Y.; Gerlach, D.; van Belle, S.; Turin, L.; Zdobnov, E.; Kaiser, L.; Tapparel, C. Identification of site-specific adaptations conferring increased neural cell tropism during human enterovirus 71 infection. PLoS Pathog. 2012, 8, e1002826. [CrossRef] [PubMed]

47. Arita, M.; Ami, Y.; Wakita, T.; Shimizu, H. Cooperative effect of the attenuation determinants derived from poliovirus sabin 1 strain is essential for attenuation of enterovirus 71 in the NOD/SCID mouse infection model. J. Virol. 2008, 82, 1787-1797. [CrossRef]

48. Zaini, Z.; Phuektes, P.; McMinn, P. A reverse genetic study of the adaptation of human enterovirus 71 to growth in Chinese hamster ovary cell cultures. Virus Res. 2012, 165, 151-156. [CrossRef]

49. Kataoka, C.; Suzuki, T.; Kotani, O.; Iwata-Yoshikawa, N.; Nagata, N.; Ami, Y.; Wakita, T.; Nishimura, Y.; Shimizu, H. The Role of VP1 Amino Acid Residue 145 of Enterovirus 71 in Viral Fitness and Pathogenesis in a Cynomolgus Monkey Model. PLoS Pathog. 2015, 11, e1005033. [CrossRef]

50. Kobayashi, K.; Sudaka, Y.; Takashino, A.; Imura, A.; Fujii, K.; Koike, S. Amino Acid Variation at VP1-145 of Enterovirus 71 Determines Attachment Receptor Usage and Neurovirulence in Human Scavenger Receptor B2 Transgenic Mice. J. Virol. 2018, 92, e00681-18. [CrossRef]

51. Fujii, K.; Sudaka, Y.; Takashino, A.; Kobayashi, K.; Kataoka, C.; Suzuki, T.; Iwata-Yoshikawa, N.; Kotani, O.; Ami, Y.; Shimizu, H.; et al. VP1 Amino Acid Residue 145 of Enterovirus 71 Is a Key Residue for Its Receptor Attachment and Resistance to Neutralizing Antibody during Cynomolgus Monkey Infection. J. Virol. 2018, 92, e00682-18. [CrossRef] [PubMed]

52. Tee, H.K.; Tan, C.W.; Yogarajah, T.; Lee, M.H.P.; Chai, H.J.; Hanapi, N.A.; Yusof, S.R.; Ong, K.C.; Lee, V.S.; Sam, I.C.; et al. Electrostatic interactions at the five-fold axis alter heparin-binding phenotype and drive enterovirus A71 virulence in mice. PLoS Pathog. 2019, 15, e1007863. [CrossRef]

53. Caine, E.A.; Partidos, C.D.; Santangelo, J.D.; Osorio, J.E. Adaptation of Enterovirus 71 to Adult Interferon Deficient Mice. PLoS ONE 2013, 8, e59501. [CrossRef]

54. Zaini, Z.; Phuektes, P.; McMinn, P. Mouse adaptation of a sub-genogroup B5 strain of human enterovirus 71 is associated with a novel lysine to glutamic acid substitution at position 244 in protein VP1. Virus Res. 2012, 167, 86-96. [CrossRef] [PubMed]

55. Xu, Y.; Ma, S.; Zhu, L.; Huang, Z.; Chen, L.; Xu, Y.; Yin, H.; Peng, T.; Wang, Y. Clinically isolated enterovirus A71 subgenogroup C4 strain with lethal pathogenicity in 14-day-old mice and the application as an EV-A71 mouse infection model. Antivir. Res. 2017, 137, 67-75. [CrossRef] [PubMed]

56. Miyamura, K.; Nishimura, Y.; Abo, M.; Wakita, T.; Shimizu, H. Adaptive mutations in the genomes of enterovirus 71 strains following infection of mouse cells expressing human P-selectin glycoprotein ligand-1. J. Gen. Virol. 2011, 92, 287-291. [CrossRef]

57. Victorio, C.B.L.; Xu, Y.; Ng, Q.; Chow, V.T.K.; Chua, K.B. Phenotypic and Genotypic Characteristics of Novel Mouse Cell Line (NIH/3T3)-Adapted Human Enterovirus 71 Strains (EV71:TLLm and EV71:TLLmv). PLoS ONE 2014, 9, e92719. [CrossRef]

58. Victorio, C.B.L.; Xu, Y.; Ng, Q.; Meng, T.; Chow, V.T.K.; Chua, K.B. Cooperative effect of the VP1 amino acids 98E, 145A and 169F in the productive infection of mouse cell lines by enterovirus 71 (BS strain). Emerg. Microbes Infect. 2016, 5, 1-14. [CrossRef] [PubMed]

59. Vignuzzi, M.; Stone, J.K.; Arnold, J.J.; Cameron, C.E.; Andino, R. Quasispecies diversity determines pathogenesis through cooperative interactions in a viral population. Nature 2006, 439, 344-348. [CrossRef] [PubMed]

60. Pfeiffer, J.K.; Kirkegaard, K. Increased fidelity reduces poliovirus fitness and virulence under selective pressure in mice. PLoS Pathog. 2005, 1, e11. [CrossRef]

61. Fitzsimmons, W.J.; Woods, R.J.; McCrone, J.T.; Woodman, A.; Arnold, J.J.; Yennawar, M.; Evans, R.; Cameron, C.E.; Lauring, A.S. A speed-fidelity trade-off determines the mutation rate and virulence of an RNA virus. PLoS Biol. 2018, 16, e2006459. [CrossRef]

62. Meng, T.; Kwang, J.; Kirkegaard, K. Attenuation of Human Enterovirus 71 High-Replication-Fidelity Variants in AG129 Mice. J. Virol. 2014, 88, 5803-5815. [CrossRef] [PubMed] 
63. Kew, O.M.; Sutter, R.W.; de Gourville, E.M.; Dowdle, W.R.; Pallansch, M.A. Vaccine-derived polioviruses and the endgame strategy for global polio eradication. Annu. Rev. Microbiol. 2005, 59, 587-635. [CrossRef] [PubMed]

64. Arita, M.; Shimizu, H.; Nagata, N.; Ami, Y.; Suzaki, Y.; Sata, T.; Iwasaki, T.; Miyamura, T. Temperature-sensitive mutants of enterovirus 71 show attenuation in cynomolgus monkeys. J. Gen. Virol. 2005, 86, 1391-1401. [CrossRef] [PubMed]

65. Kung, Y.-H.; Huang, S.-W.; Kuo, P.-H.; Kiang, D.; Ho, M.-S.; Liu, C.-C.; Yu, C.-K.; Su, I.-J.; Wang, J.-R. Introduction of a strong temperature-sensitive phenotype into enterovirus 71 by altering an amino acid of virus 3D polymerase. Virology 2010, 396, 1-9. [CrossRef]

66. Huang, S.-W.; Huang, Y.-H.; Tsai, H.-P.; Kuo, P.-H.; Wang, S.-M.; Liu, C.-C.; Wang, J.-R.; Pfeiffer, J.K. A Selective Bottleneck Shapes the Evolutionary Mutant Spectra of Enterovirus A71 during Viral Dissemination in Humans. J. Virol. 2017, 91, e01062-17. [CrossRef]

67. Chu, S.T.; Kobayashi, K.; Bi, X.; Ishizaki, A.; Tran, T.T.; Phung, T.T.B.; Pham, C.T.T.; Nguyen, L.V.; Ta, T.A.; Khu, D.T.K.; et al. Newly emerged enterovirus-A71 C4 sublineage may be more virulent than B5 in the 2015-2016 hand-foot-and-mouth disease outbreak in northern Vietnam. Sci. Rep. 2020, 10, 159. [CrossRef] 